\title{
Two Sun over One Firmament Culture: A Political-Communication Analysis on the Contestation of Jakarta and Kuala Lumpur over "Indonesian Malay Communities"
}

\author{
Evie Ariadne Shinta Dewi ${ }^{1, *}$ \\ ${ }^{1}$ Universitas Padjadjaran, Indonesia
}

\begin{abstract}
This paper tries to extent a personal experience on an interesting discussion concerning the communication issues in Medan, North Sumatra. There is the inclination of the North Sumatrans to the news broadcasted by Kuala Lumpur and Medan's tends to identify with its cultural similarities. For Jakarta is officially the center of political authority over the 'Indonesian Malay Communities', this dual cultural loyalty creates an imaginary phenomenon: 'Two Suns' in term of authoritative news resources that applies upon 'One Firmament Culture'. This means that there is a divided news orientation among the Indonesian Malay Communities' that put Jakarta and Kuala Lumpur in a tacit contestation. While until today this kind of contestation is still going on, the same features have brought me to the phenomenon of hierarchical communication structure. This vividly seen when we realize how lopsided is in nature the communication relations between the global authorities who have controlled the strategic means of communications as well as their contents with the rest of the world. For, in exception to technological matters, the Kuala Lumpurinclined of 'the Indonesian Malay Communities' in communication practices is based more on cultural aspects than their technical and political necessities words.
\end{abstract}

\section{Introduction}

There something stuck the thought of an interesting fact related to dual cultural loyalty that prevails within the people of North Sumatra as by Gelora Viva, Head of Postel Infocomm Department of North Sumatra office:

"Di Sumatera Utara ini posisinya dekat dengan Malaysia, sedangkan Jakarta tidak. Sementara semua peraturan dibuat di Jakarta. Akibatnya kita tidak punya benteng di pesisir timur dari segi Televisi sementara TV Malaysia dapat diterima dengan baik. Informasi dari Luar bebas masuk sementara yang dari dalam justru masih terhambat. Akibatnya kita akan terganggu secara Ipoleksosbudhankam (ideologi, politik, ekonomi, sosial, budaya, pertahanan dan keamanan). Soal Pilkada (pemilu kepala daerah) di

*Corresponding author: evieasd@gmail.com, evie@unpad.ac.id 
Medan ini malah dibandingkan dengan pilkada di Malaysia tidak dibandingkan dengan Jakarta. Hal lain, soal pertumbuhan ekonomi, di Sumut tidak tergantung Jakarta, makanya pertumbuhan ekonomi di sini lebih tinggi jika dibandingkan di Jakarta." (North Sumatra, is close to the position of Malaysia, while Jakarta is not. While all rules are made in Jakarta. As a result we do not have a fort on the east coast of Malaysia in terms of the TV while the Malaysia's TV can be received well. Information from Outside entry freely while on the inside it is still hampered. As a result, we would be disturbed by Ipoleksosbudhankam (ideology, politics, social, culture, defence and security). People prefer compare Pilkada (regional election) with local election in Malaysia does not compare to Jakarta. Economic growth in North Sumatra does not depend Jakarta, so that's why economic growth is higher here than in Jakarta.) "

As will be mentioned later, taking a different historical path with their Javanese fellow, the North Sumatran people share their cultural traits with other people that geographically separated from the official lines of Indonesia. This, at its turn, creates a kind of dual cultural loyalty within this people. It is at this juncture, it deserves to raise a conceptual question: Is the Jakarta's influence - as a center of government and the center of national political authority - penetrative enough, on the matters of spreading cultural information, into its national peripheral areas, especially in North Sumatra?

Exploring the Sundanese and the Javanese, and compared with other Indonesia's myriad ethnic groups, which both of these people share much more similarities. And unconsciously, both of the peoples see themselves as the center of Indonesia's culture. Cultural communication between them, therefore, would be going much smoothly, simply because the shared cultural values running within the core geographical boundaries of Indonesia. When this perspective is used to see the North Sumatran and its adjacent peoples whom would call them as, "the Indonesia's Malay communities", we would fine an interesting phenomenon in terms of cultural communication and cultural loyalty. By going deeper into this subject matter, I think the scene is worth enough to be shared here.

\section{Global power and the lopsided communication contestation}

It is undeniably that the dominance influence of the developing countries' capital cities as a sole source of cultural information are increasingly challenged by the outside forces or actors. In other hand, the field of communication is the structures of information current that naturally run in the form of mutual exchange. In a sense that the communication processes cannot take place in a unilateral way, or in other words, transmitted information must getting responses from the communicants [1]. So, Jakarta as a capital cities and source of information have to perform the credibility's communicators to the community, except people will leave and looking for other credible source of information, like neighbor country, Malaysia. Furthermore since the 21st century, information is the central theme of the researchers. People currently live in the information age that provides a variety of information technology such as the internet and mobile phones. Manuel Castell [2], try to define and explain the information age between the years 1996-1998 through the theory he had made and presented network society as a social structure characterized by a network of communication and information-processing technology, "the network society as a social structure is ccharacterized by networked communications and information processing technologies", said Castell.

To observe North Sumatran's people's behavior, aside from Castells's information theory, we can also use the concept of Media Flow, which is built from a series of studies since 1970-1980an, which researchers claim their unbalanced, unidirectional flows of TV Programs and foreign news from the "center" to the "periphery". It is evident that one of the 
phenomena of intense from the North Sumatrans networking society is inequality of information dissemination. Analyzing information about inequality, we can use the Media Imperialism Concept. Where the concept was built "within a broader analysis of cultural imperialism and dependency theories". As stated by Barrett "the process whereby the ownership, structure, distribution of the content of the media in any one country are singly or together subject to substantial external pressures from the media interests of any other country or countries without proportionate Reciprocation of influence by the country so affected [3]. Referring to the concept of Media Imperialism, we can see Jakarta as the center of power and in some cases; also the culture of course is one of the actor's disseminators of information. But faced with global actors with great imagination and control of it makes the position even Jakarta serves only as the recipient of the communication flow transmitted by actors giants.

There is unquestionable that those who involve in the communication process are tend to be pluralistic, the quality, and above all, the power of the communication contents are increasingly concentrated in the hands of a handful centers of actors. This has brought about its qualitative nature, namely a communication situation that freely place every participant mutually exchange within the framework of equal status, simply does not work. In other words, through the fast development of technological information and communication, the quality, the contents or resources of communication have been massively shifting to a more world-wide conglomerated centers that they are even able to dictate the structure of world peoples' imagination.

Quoting Paul Kennedy, these MNCs stress their interests more with international rather than national that structurally put their influence beyond the borders of their national geographic areas. It is the growth of these MNCs that bringing the world to the communication technology revolution. This phenomenon is clearly depicted by Kennedy:

They existed, in embryonic form, in the cosmopolitan private bank of the late nineteenth and early twentieth centuries, whose growth was assisted by the earlier 'communication revolution' of the telegraph and by the absence of major Great Power coalition wars. But today's globalization is distinguished from those earlier examples by the sheer quantity and extent of the multinational firms in our expanded and integrated global economy. As noted above, they emerged in the postwar international economic order that reduced protectionism and encouraged a recovery of world trade, and were further stimulated in the 1970s by the United States' decision to abandon the gold standard followed by a general liberalization of exchange controls, at first only in a few countries, later in many others. This not only provided more liquidity for world trade, but increased the flow of transnational capital investments, as companies invested abroad without constraints imposed by central banks [4].

At least, there are three points that could be drawn from these paragraphs. First, the laden economic interests of the MNCs had driven them to pursue further communication technological developments. Through these technologies, the MNCs were able to develop an effective communication in controlling their capital investments. Second, although the spread of information seemingly confined strictly within the space of economic interests of those corporations, it's by product had gone beyond these frontiers. The needs to spread the capital investments world-wide, for instance, invariably require a wider and a more sophisticated communication networks at global level. Third, through such a typical process, we witness the creation, though had gone gradually, a hierarchic structure in the practice of communication. It is within the third element drawn from those paragraphs we see the autonomous expansive development of the power of a handful center of actors, who possess the means of technological communication, in dictating the quality and contents of communication - that then influence the rest of the world. In other words, it is they who 
have the actual right to determine what kind of information should be spread out to the world public.

The hierarchical structure of information transmission running through the uneven power in commanding the communication technologies. As the consequence, the forms, contents and the quality of information that are determined to be disseminated by them practically biased to their cultural background. By possessing and commanding the technological information, it is they who define the superiority of expressions. Namely, the expressions that can be found in various instructive novels, movies or other cultural creations that confiningly derived from a single world of culture. Since the rest of the world possess no control over the means of communication, the world-wide spread of these superior expressions - centered among a handful of actors - have gradually and inevitably become a global norms. Having superior in contents and being spread through the sophisticated means of communication, the messages they send to the world public will unconsciously tend to be accepted as the "final truth".

This lopsided disseminating information power had clearly analysed by Edward Said his monumental book Orientalism [5] where which all of the miseries produced by the Middle-East perennial conflicts were blamed into the hands of the Arabs, chiefly the Palestinian, responsility. And the terrorist stigma putting upon the shoulders of the Arabs had been perceived as a "truth" at the global public arena.

It is in this context we are witnessing the decline of power of the developing countries' capital cities in controlling the swirl communication contents around them, simply because they possesses no authoritative communication sources as well as and effective and sophisticated technological communication to compete with. Instead of being able to create their own communication power, these developing countries' capital cities have become the powerless recipients of information fanned by the global central actors who command both technologies and information resources. This weakening position is also the case with Jakarta, as the core of Indonesia's power and political authority - and to some extent is fighting to get the status of the center of its own national culture too.

Theoretically, as the center of centers within national boundary of Indonesia, Jakarta should take a central role in communication affairs for the whole of Indonesian people. In practice, however, this limitedly applies to the current of information concerning merely on political issues, administrative regulations that centrally transmitted from Jakarta. But, in the field of cultural issues and system of ideas, the centrality of the Jakarta's position remains problematic. For, in reality, instead of being the main actor in the field of communication, Jakarta less articulative and is often merely being able to act as a recipient before the huge wave of world-wide transmitted communication contents.

This is vividly seen when it is being faced against the global actors who control both of the world cultural imaginations and expressions and technical means of communication. Movies such as Spider Man, Iron Man, Frozen or intellectual phrases such as Schumacher's small is beautiful and Anthony Giddens' Third Wave take their gound much deeper into the national public mind compared with a series of the Indonesia's president or the elite of political parties addresses or the national strategic groups' point of views.

These all provide an undeniably fact that the aforementioned actor pluralism's assumption in the communication processes, in a sense the dyadic mutual exchanges in ideas and information, stands on a weak ground. What really happening on the stage are the sheer majority of recipients and the handful centers or actors who hold and control the disseminators of information within the system of communication affairs. By looking at this phenomenon, it could hypothetically be stated that —as the case with other developing countries' capital cities- the Jakarta's influence position in this world-wide communication field is less penetrative over the national public. And that all of the 
prevailing public discourses are borrowed from those that centrally produced by the global actors.

\section{Cultural Contestation between Jakarta and Kuala Lumpur}

Through the global phenomena described earlier, instead, the distinctive structures of the North Sumatra's physical geography that makes Semenanjung Melayu (Malay Peninsula) of Malaysia much closer compared with other areas within the span of Indonesian frontiers. This specific geographical location thus facilitates and heightened the frequencies of huge wave back and forth movements of both North Sumatran and Malaysian populations. As a result, these undisturbed geographical people movements strengthen the old and historic cultural pattern of relations between the North Sumatrans and the Malaysian people. At its turn, this refreshing and strengthening cultural relations provides the North Sumatran population access into another actors who control the source of cultural values and information alternative to Jakarta.The North Sumatran, the Acehnese, the Jambi people, and the West Sumatran are looked culturally more as "the Indonesian Malay communities" than a general feature that generally marking "Indonesians". Sharing the cultural system, these "Indonesian Malay communities" established deep and long emotional bound with the people of Tanah Semenanjung, whose path development is not shared with both Jakarta and Javanese-Sundanese people as a whole.

The unavoidable contestation between Jakarta and the center of the Malay Culture in the area of communication soon comes into existence as Kuala Lumpur managed to gain "supremacy" in terms of its national economic performance at regional level, namely among the ASEAN countries. In this case, Kuala Lumpur, as the center of Malay culture, has not only proven itself to be one of the leaders among the ASEAN level, but also has successfully transformed the Malaysian society in accordance to modern ways. This is remarkably shown by looking at the legacy of Mahathir Muhammad's development programs which a tremendous success. Leading this country since the early 1980s, Mahathir ultimately brought the state and the Malaysian society into an unprecedented development success story. It is at this point Jakarta potentially fail to be a single penetrative communication power upon the "the Indonesian Malay communities", although undeniably they are geographically exist within its sovereign boundaries. For, as has been stated, the success of Kuala Lumpur in economic development refreshing the collective memory among the Malay constituent culture about their past emotional bound. In other words, through the impressive Kuala Lumpur economic progression, "the Indonesian Malay communities" found their modern cultural model alternative to Jakarta. Kuala Lumpur, therefore, presents itself as a dignified model for these communities.

It is in this context we see the Jakarta's position in the communication realm becomes problematic. On the one hands, "the Indonesian Malay communities" perceive the success of Kuala Lumpur leadership as a signal that their cultural system possesses value network that supportive to modern development goals. As a consequence, Kuala Lumpur could potentially be one of the centers of cultural loyalty of these "Indonesian Malay communities". On the other hands, since having cultural differentiation, "the Indonesian Malay communities" regard Jakarta confiningly functions as the center of political and administrative authority. As has been mentioned earlier, this happens because historically their cultural relations with Jakarta and Java had gone less deeper compared with the Tanah Semenanjung. The effective colonial administration (1830-1942) did integrate, in the past, the geographical parts into one nation what is known today as Indonesia. The government, however, could not go beyond this line. One of its consequences is the Jakarta's failure to shift the cultural loyalty of these "Indonesian Malay communities" totally to itself. 
However, strong political relations with Jakarta have been taking a different way with their cultural orientations. It could be assumed, then, that "the Indonesian Malay communities' relations with Jakarta is characterized more "political nationalism" and, thereby, less cultural in nature. In other words, while the national political integration between both of them is conspicuously seen, its cultural integration remains to be seen. It means that these cultural orientation and loyalty are still being contested between Kuala Lumpur and Jakarta.

It seems "the Indonesian Malay communities" relatively independent from Jakarta in terms of communication materials, for they have greater information access from the neighbouring countries, chiefly Malaysia. Entertainment programs, international news, consumer goods advertisings and global economic situation that are being broadcasted from the neighbouring country's mass media endlessly intrude into the families' rooms of "the Indonesian Malay communities". For the time being, this all could be used as the indicators of the Indonesian Malay communities' preference to the information produced by Malaysian Kuala Lumpur news networks. Is should be stressed here that sharing the historic common cultures between "the Indonesian Malay communities" and the Kuala Lumpur-centered Tanah Semenanjung communities plays its own role.

It mean for Jakarta in the context of communication, is that the Jakarta's effectiveness in presenting itself into "the Indonesian Malay communities" could not achieve its total goal - for the absent of cultural-emotional bound. The still Kuala Lumpur slanted of the Indonesian Malay communities' cultural orientation gives a vivid example about the continued "divided" cultural loyalty among these communities between Jakarta and Kuala Lumpur. It means that the information dissemination between Jakarta and Kuala Lumpur remains in the endless contestation process within "the Indonesian Malay communities". In this case, "the Indonesian Malay communities" face or possess two suns of cultural orientations: Jakarta and Kuala Lumpur that naturally presents a dual cultural leadership. For this has been going decades-long, it seems that the contestation would not end in the near future.

\section{Conclusions}

To win this contestation, Jakarta must build a communication strategy that fully garbed with cultural contents. Only by formatting its strategy full with cultural contents could Jakarta replacing the supremacy position of Kuala Lumpur and superimposing its own terms in the realm of effective communication. As the core of a sovereign state, culturally, Jakarta must be the only sun upon "the Indonesian Malay communities".

\section{References}

1. E.A. Griffin, A First Look at Communication Theory, (5 ${ }^{\text {th }}$ ed, McGraw-Hill, 2003)

2. M. Castell, The Network Society, The Power of Identity, and the End of the Millennium, (1996, 1997a, 2000)

3. O.B. Barrett, Media Imperialism Concept, (1977)

4. P. Kennedy, Preparing for the Twenty-First Century, (New York: Vintage Books, 1993)

5. E.W. Said, Orientalism : Western Conception Of The Orient, (London : Penguin Books, 1978) 